\title{
TRMM rainfall estimative coupled with Bell (1969) methodology for extreme rainfall characterization
}

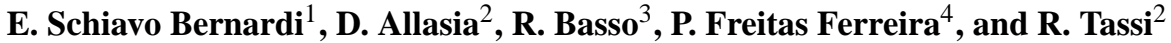 \\ ${ }^{1}$ University of Santa Maria, Programa de Pós-graduação em Engenharia Ambiental, Santa Maria, Brazil \\ ${ }^{2}$ University of Santa Maria, Sanitary and Environmental Engineering/PPG Eng. Civil/PPG Eng. Ambiental, \\ Santa Maria, Brazil \\ ${ }^{3}$ University of Santa Maria, Programa de Pós-graduação em Engenharia Civil, Santa Maria, Brazil \\ ${ }^{4}$ University of Santa Maria, Curso de Engenharia Sanitaria e Ambiental, Santa Maria, Brazil \\ Correspondence to: D. Allasia (dga@ufsm.br)
}

Received: 23 April 2015 - Accepted: 23 April 2015 - Published: 11 June 2015

\begin{abstract}
The lack of rainfall data in Brazil, and, in particular, in Rio Grande do Sul State (RS), hinders the understanding of the spatial and temporal distribution of rainfall, especially in the case of the more complex extreme events. In this context, rainfall's estimation from remote sensors is seen as alternative to the scarcity of rainfall gauges. However, as they are indirect measures, such estimates needs validation. This paper aims to verify the applicability of the Tropical Rainfall Measuring Mission (TRMM) satellite information for extreme rainfall determination in RS. The analysis was accomplished at different temporal scales that ranged from 5 min to daily rainfall while spatial distribution of rainfall was investigated by means of regionalization. An initial test verified TRMM rainfall estimative against measured rainfall at gauges for 1998-2013 period considering different durations and return periods (RP). Results indicated that, for the RP of 2, 5, 10 and 15 years, TRMM overestimated on average $24.7 \%$ daily rainfall. As TRMM minimum time-steps is $3 \mathrm{~h}$, in order to verify shorter duration rainfall, the TRMM data were adapted to fit Bell's (1969) generalized IDF formula (based on the existence of similarity between the mechanisms of extreme rainfall events as they are associated to convective cells). Bell's equation error against measured precipitation was around 5-10\%, which varied based on location, RP and duration while the coupled BELL+TRMM error was around 10-35\%. However, errors were regionally distributed, allowing a correction to be implemented that reduced by half these values. These findings in turn permitted the use of TRMM+Bell estimates to improve the understanding of spatiotemporal distribution of extreme hydrological rainfall events.
\end{abstract}

\section{Introduction}

Characteristics of heavy rainfall events are important in the design of hydraulic structures, agriculture, weather modification, and in monitoring climate change (Angel and Huff, 1997). However, due to its highly complex spatiotemporal distribution its correct quantification is normally possible only through a dense rain gage network with quality data. This kind of network is financially unviable due to the high costs of monitoring and maintenance involved, especially in developing countries with large territorial extensions as Brazil (Fensteinseifer et al., 2013a).
The Brazilian Southernmost State of Rio Grande do Sul (RS), a region characterized as a temperate climate with a mix of frontal and convective rainfall, has also difficulties in monitoring rainfall data. A quick research in the National Water Agency and National Weather Service of Brazil databases (in Portuguese known simply as ANA and INMET respectively) will show 881 daily rainfall gauges distributed in the $281730.22 \mathrm{~km}^{2}$ of the state. However, a closer look will indicate that only 522 stations have public data, and many of them with large periods of faulty data. When the focus is on shorter duration rainfall gauges, the research will show less than 30 stations with data, many of them with 
records still on paper, and that are not easily shared with researchers.

Therefore, it is important to analyze and understand extreme rainfall behavior in this area by others means, where a drought and the great flood that followed in the beginning of 2010 's caused an overall loss estimated in $5 \%$ of the State's GDP (RS contributes in turn with $7 \%$ of Brazil GDP).

In order to supply these deficiencies satellite rainfall estimation has been explored because of several advantages like measuring spatial variability of rainfall, being rapidly and in general freely available on the Internet, and maintaining functionality even during catastrophic situations that can temporarily shut down ground networks (e.g., overland effects of hurricanes) (Fensteinseifer et al., 2013a).

Currently, the data provided by the Tropical Rainfall Measuring Mission (TRMM) are the most widely used satellitebased rainfall estimates. It was launched in 1997 as the first mission dedicated to measure tropical and subtropical rainfall. It follows a low-altitude orbit of $350 \mathrm{~km}$ (in 2001 raised to $402 \mathrm{~km}$ ) and a declination of $35^{\circ}$ to the Equator (Kummerow et al., 2000), resulting in 16-daily orbits around Earth allowing the satellite to pass over most tropical locations either once or twice a day. TRMM uses radiances or brightness temperatures estimates from clouds to determine the potential rainfall with a resolution of $0.25^{\circ} \times 0.25^{\circ}$. Multispectral microwave sensors have the ability to penetrate into the clouds and, hence, to estimate rainfall after processing collected data through several algorithms, other satellites (geostationary and polar orbit), and observed precipitation data from Earth in the TRMM Multi-satellite Precipitation Analysis (TMPA) (see Huffmann et al., 2010, for more details).

TRMM products have been used in many places to supply rainfall information when conventional data are scarce (Kummerow et al., 2000) and consequently it has been compared with conventional observations and other satellite derived products (Barret et al., 1994; Adler et al., 2001; Nicholson et al., 2003; Fisher, 2004; Nóbrega et al., 2008; Huffmann et al., 2010; Fensteinseifer et al., 2013a, b, among others). The results by these researchers vary with several factors, ranging from TRMM data version (currently 7) to location, but for practical reasons could be assumed that correlation coefficient (CC) of daily rainfall against TRMM's estimated rainfall is around $70-90 \%$, while this value is up to $90-98 \%$ when monthly rainfall is analyzed. Particularly, values obtained by Fensteinseifer et al. (2013b) for RS's central region shows CC between 0.46 and 0.82 for daily time step and between 0.67 and 0.95 for monthly time step depending on location, and regionally overestimating daily rainfall by $11 \%$.

However, TRMM rainfall data has a minimum temporal resolution of $3 \mathrm{~h}$ that is far from heavy rainfall estimation necessity for several types of projects, such as, urban drainage. Due to this, it must be desegregated in some way to obtain information about shorter duration periods. Between the methodologies for this purposes could be mentioned the ratio between rainfall of different durations (Hershfield and Wilson, 1958), hourly or sub-hourly rainfall modeling associated with stocastic disagregation models (e.g. Rodriguez-Iturbe et al., 1987; Koutsoyiannis and Xanthopoulos, 1990; Glabsey et al., 1995; Damé, 2001) and some worldwide generic heavy rainfall equations such as Bell (1969) or Chen (1983), or the much more improved equation presented by Koutsoyiannis (2004) and Koutsoyiannis and Baloutsos (2000) with an ampplication for TRMM data by Endreny and Imbeah (2009)

Specifically Bell (1969) proposed an equation (Eq. 1) based on the idea that heavy rainfall with durations of up to two hours are normally caused by convective rainfall cells that have similar behavior independent of the location. Within this assumption, rainfall for any return periods (RP) and duration (below $2 \mathrm{~h}$ ) could be estimated just from rainfall with a duration of one hour and a RP of 10 years.

$P_{t}^{T}=(0.21 \ln T+0.52)\left(0.54 t^{0.25}-0.50\right) P_{60}^{10}$

where $P_{t}^{T}$ is the $T$-year and $t$-min rainfall depth in $\mathrm{mm}$; and $P_{60}^{10}$ the 10 -year, $1 \mathrm{~h}$ rainfall depth in $\mathrm{mm}$. Equation (1) is valid for partial series and for RP 2 years $<T<100$ years and 5 min $<t<120$ min.

In this light, this paper aims to verify the applicability of the Tropical Rainfall Measuring Mission satellite information for extreme rainfall determination in RS state extending its application for shorter duration rainfall by means of Bell's (1969) equation. Among the methods, worldwide generic heavy rainfall equations were selected because its simplicity, more suitable for the Engineering Technicians and Technologists that normally works in small municipalities. In particular, Bell's (1969) was chosen over other mentioned methodologies due to less data requirement.

\section{Data and methods}

Daily and sub-daily rainfall data from 12 locations (Fig. 1b) around RS state were selected because data availability. Subdaily rainfall was derived from existing IDF by Denardin and Freitas (1982) or rainfall ratio for different durations against $24 \mathrm{~h}$ rainfall published by Beltrame et al. (1991) spanning the period 1960's-1980's. Daily rainfall was obtained from INMET for the period 1998-2013 coincident with TRMM data availability.

Rainfall gauge data was compared against rainfall estimated by the $3 \mathrm{~B} 42$ product of the TMPA. It is important to note that 3B42 pixel represents rainfall in an area of $625 \mathrm{~km}^{2}$, and it has been put side by side against the rainfall gauge that lies within the pixel in a similar manner to what a technician is expected to use. In any case, there is no reliable method to compare punctual information (gauge) with estimate rainfall by satellite with such a low spatial resolution and results include this uncertainty.

Initially, by using Gumbel extreme distribution was determined daily rainfall with return periods ranging from 2 


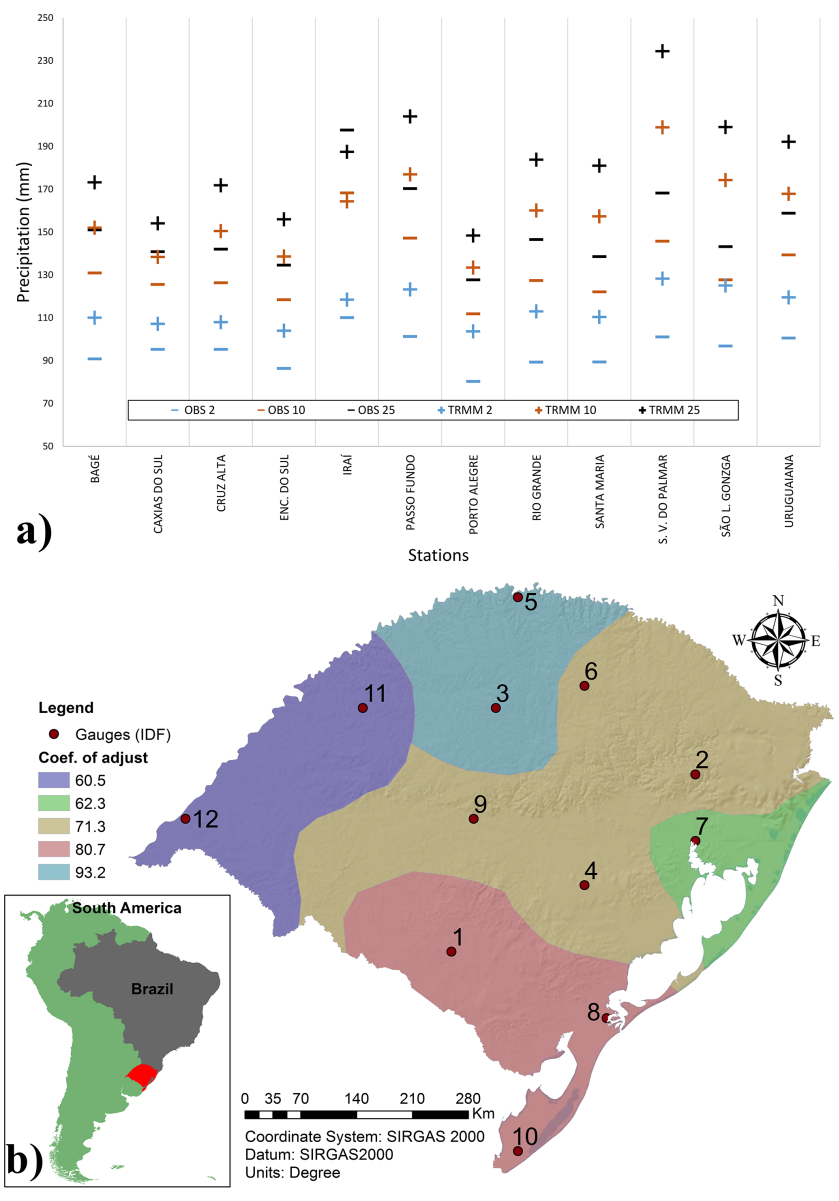

Figure 1. (a) Local variations between TRMM estimative and rainfall gauges. (b) Regions of maximum precipitation and TRMM adjustment coefficients.

to 100 years from INMET gauges and 3B42 (3B42's 3 hourly rainfall was grouped in order to match available daily records). The results permitted to compare probabilistic behavior of observed and satellite-based rainfall.

Later, was compared the probabilistic behavior of subdaily precipitation between 3B42 and observed rainfall by means of Bell's (1969) equation. In order to fit Bell's equation, the $P_{60}^{10}$ used by Bell's (1969) equation (Eq. 1) was obtained multiplying the daily 10 -year return period precipitation obtained in the previous step (either from observed or $3 \mathrm{~B} 42)$ by the ratio between $1 \mathrm{~h}$ and $24 \mathrm{~h}$ rainfall $\left(R_{1 \mathrm{~h} 24 \mathrm{~h}}\right)$ as determined from Denardin and Freitas (1982) and Beltrame et al. (1991) following the methodology proposed by Hershfield and Wilson (1958).

As Bell's equation only relies in $P_{60}^{10}$ for the determination of precipitation for every duration and return period, estimating a corrections to this value permits to adjust the results. In this light, an adjustment coeficient $\left(C_{\text {adj }}\right)$ that multiplies $3 \mathrm{~B} 42 \mathrm{P}_{60}^{10}$ at every station was also estimated.
Combining the $C_{\text {adj }}$ distribution with hydroclimatological information such as climatic characterization of RS (Rossato, 2011), mean annual precipitation map (CPRM, 2011) and the seasonal rainfall characterization of RS (Britto et al., 2006) was possible to regionalize results. Finally, within these regions, the TRMM data were adapted to obtain generalized IDF.

\section{Results and discussions}

Regarding the daily rainfall with RP ranging from 2, 10 and 25 years, the TRMM overestimated the values obtained from rainfall gauges data on average by $24.8 \%$ with a standard deviation of $11.2 \%$ (Fig. 1a). These results are coincident with Gonçalves (2011) that in a broader analysis of Brazil, indicated that TRMM rainfall only in Southern Brazil was above the estimated in rainfall gauges. Gonçalves (2011) also indicated that the differences between both dataset showed regional changes.

Considering the regional differences between both datasets, at every station was determined the $C_{\text {adj }}$ that multiplied the 3B42 daily 10-year RP results in order to match results obtained from surface observation network. In the sequence, as already mentioned, $C_{\mathrm{adj}}$ information was combined with Rossato (2011), CPRM (2013) and Britto et al. (2006) to determine regions with a distinct $C_{\text {adj }}$.

Following the mentioned authors, the five regions (Fig. 1b) were characterized based on the fact that the state is influenced by three air masses: Atlantic Tropical Mass (ATM), Continental Tropical Mass (CTM) and Atlantic Polar Mass (APM). The ATM, which is warm, humid and presents a tendency to stability, operates mainly in the Eastern region. In Western and Northern region, the CTM (warm and dry) predominates. However, in the Northwestern region occurs a blockage of CTM due to ATM action, favoring the continuous rainfall occurrence. The Southern region is strongly influenced by APM (cold). In Central/Northeast region there is a strong influence of topography as the relief causes instability in the air masses movements which, in turn, promote convective rainfall occurrence (Britto, 2006; Rossato, 2011).

With the regionalized coefficient, the Bell (1969) equation was transformed into (Eq. 2):

$$
\begin{aligned}
P_{t}^{T} & =(0.12 \ln T+0.52) \cdot\left(0.54 t^{0.25}-0.50\right) \\
& \cdot\left(P_{\mathrm{TRMM}}^{10} \cdot C_{\mathrm{adj}} \cdot R_{1 \mathrm{~h} 24 \mathrm{~h}}\right)
\end{aligned}
$$

where $P_{t}^{T}$ is the $T$-year and $t$-min rainfall depth in mm; $P_{\text {TRMM }}^{10}$ is the 10-year, 1 day rainfall depth in mm determined from 3B42, $C_{\text {adj }}$ is the adjustment coefficient to deal with daily rainfall estimative error, and $R_{1 \mathrm{~h} 24 \mathrm{~h}}$ is the ratio between one hour and $24 \mathrm{~h}$ rainfall.

For a first verification, one station within each region was compared to the regional equation (Fig. 2). Results for 10year RP rainfall for different durations were plotted for: 


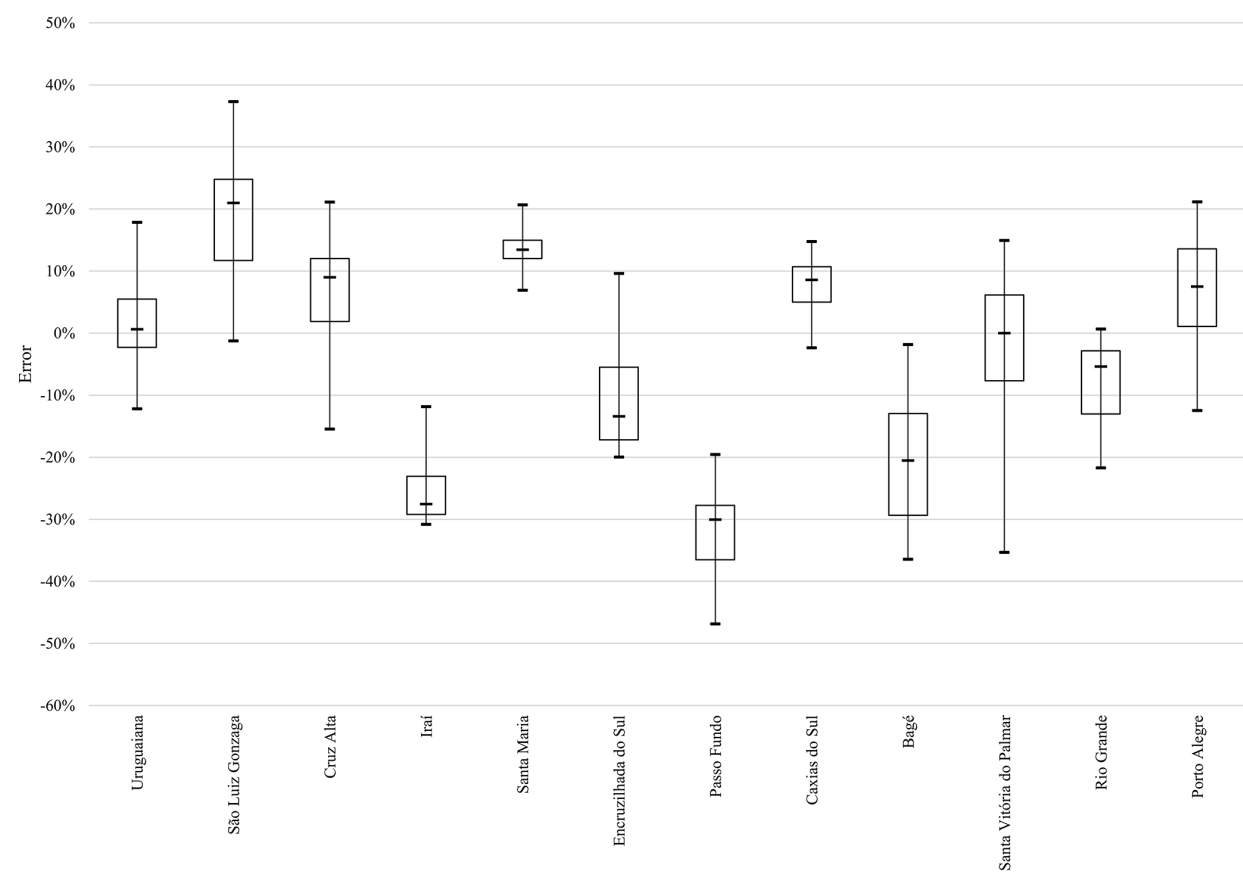

Figure 2. Behavior of IDF, Bell, TRMM and TRMM adjusted set in the North (a), East (b), Central/Norteast (c), West (d) and South Regions (e).

(a) the original Bell equation based on rainfall gauge data (in results just named BELL - Eq. 1); (b) IDF relationship obtained from Denardin and Freitas (1982) or Beltrame et al. (1991); (c) Bell's relationship using TRMM data as input (just TRMM); and (d) Bell's equation using corrected TRMM data (TRMM adjusted).

The North Region (Fig. 2a), was the unique to present a large similarity between IDF, BELL, TRMM and

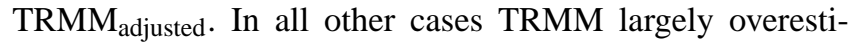
mated rainfall. Only in the North and East regions, BELL and IDF results where similar, suggesting that BELL equation better represent rainfall influenced by ATM action and clearly overestimate rainfall where CTM and APM predominate. These results are somehow expected as Bell's method lack of a location parameter (as already present in Chen, 1983; Koutsoyiannis, 2004). In any case, TRMM adjusted was $_{\text {a }}$ able to represent rainfall reasonably well in all regions, except in the South region (Fig. 2e), where APM action predominates. Considering the shortage of data, the region should be analyzed in more detail and, perhaps, subdivided.

The boxplot graph (Fig. 3) allows to verify error's variations of TRMM adjusted $_{\text {when compared with the IDF at each }}$ station. It is observed that Santa Maria and Caxias do Sul gauges had minor variations of the data, which may have been influenced for a best adjust coefficient in Central region. The data variation was large in the stations located in the South region (Bagé and Santa Vitória do Palmar), reinforcing Bell's limitation when dealing with regions mostly affected by Polar masses. Most locations showed little vari-

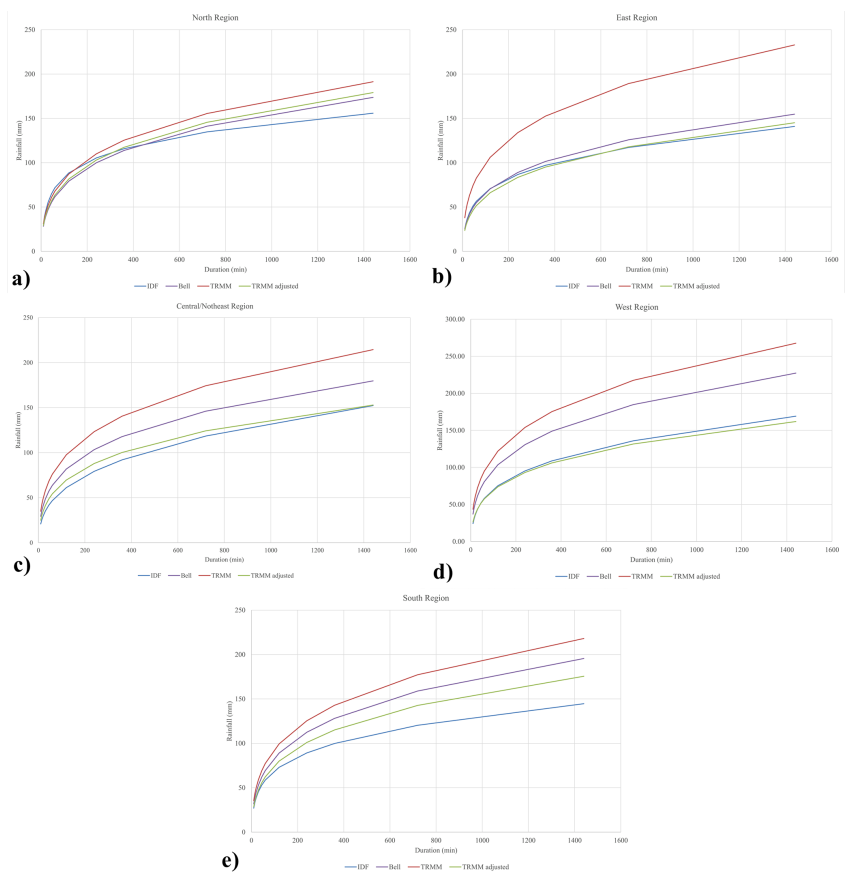

Figure 3. Errors between $\mathrm{TRMM}_{\text {adjusted }}$ and IDF at each location.

ation between the first and third quartile, indicating that deviations from IDF results are similar for different durations and returns periods. 


\section{Conclusions}

These results show the large potential of a simple general IDF equation as Bell's (1969) to describe and understand the spatial and temporal distribution of extreme hydrological events involving heavy rainfall in Southern Brazil, when associated with TRMM estimate. This is important for a region with data scarcity, especially for shorter durations rainfall. However, the results suggest the need of more detailed studies in the region affected by Polar masses, were probably only the improved generalized IDF's presented by Chen (1983) or Koutsoyiannis (2004) may be the solution. However the lack of data, that already motivated this analysis, is a limitation to the studies through more detailed techniques.

Acknowledgements. The first author thanks the FAPERGS (Fundação de Amparo à Pesquisa do Estado do Rio Grande do Sul) and the third CAPES/Brazil for financial support for this research.

\section{References}

Adler, C., Petty, G., Morissey, M., and Goodman, H. M.: Intercomparison of global precipitation products: The third Precipitation Intercomparison Project (PIP- 3), B. Am. Meteor. Soc., 82, 1377-1396, 2001.

Angel, J. and Huff, F.: Changes in Heavy Rainfall in Midwestern United States, J. Water Resour. Plann. Manage., 123, 246-249, 1997.

Barrett, E. C., Adler, R. F., Arpe, K., Bauer, P., Berg, W., Chang, A., Ferraro, R., Ferriday, J., Goodman, S., Hong, Y., Janowiak, J., Kidd, C., Kniveton, D., Morrissey, M., Olson, W., Petty, G., Rudolf, B., Shibata, A., Smith, E., and Spencer, R.: The first WetNet Precipitation Intercomparison Project: Interpretation of results, Remote Sens. Rev., 11, 303-373, 1994.

Bell, F. C.: Generalized rainfall-duration-frequency relationships, J. Hydrol. Eng. Div-ASCE, 95, 311-327, 1969.

Beltrame, L. F. S., Lanna, A. E. L., and Louzada, J. A. S.: Intense Rainfall (Chuvas Intensas), Porto Alegre, p. 69, 1991.

Britto, F. P., Barletta, R., and Mendonça, M.: Seazonal regionalization and monthly rainfall high precipitation in Rio Grande Do Sul state (Regionalização sazonal e mensal da precipitação pluvial máxima no estado do Rio Grande Do Sul), Rev. Brasil. Climatol., 2, 35-51, 2006.

Chen, C.: Rainfall Intensity-duration-frequency formulas, J. Hydrol. Eng.-ASCE, 109, 1603-1621, 1983.

CPRM: Brazil Atlas Rainfall (Atlas Pluviométrico do Brasil), avaliable in CD ROM, November 2011.

Damé, R. C. F.: Breakdown of daily rainfall to estimate intensityduration-frequency curves (Desagregação de precipitação diária para estimativa de curvas Intensidade-Duração-Frequência). Tese (Doutorado em Engenharia de Recursos Hídricos e Saneamento Ambiental), Universidade Federal do Rio Grande do Sul. Instituto de Pesquisas Hidráulicas, Porto Alegre, RS, 131 pp., 2001.
Denardin, J. and Freitas, P. L.: Fundamental characteristics of rain in Brazil (Características fundamentais da chuva no Brasil), Pesquisa Agropecuária Brasileira, 17, 1409-1416, 1982.

Endreny, T. A. and Imbeah, N.: Generating robust rainfall intensityduration-frequency estimates with short-record satellite data, J. Hydrol., 371, 182-191, doi:10.1016/j.jhydrol.2009.03.027, 2009.

Fenterseifer, C. A.: Qualidade das estimativas de precipitações derivadas de satélites na bacia hidrográfica do rio Jacuí - RS, M. S., Programa de Pós-Graduação em Engenharia Civil e Ambiental, Universidade Federal de Santa Maria, Santa Maria, 126 pp., $2013 b$.

Fensteinseifer, C. A., Allasia, D. G., Favaretto, J., and Tassi, R.: Investigation of Urban-Induced rainfall in Porto Alegre, Brazil using TRMM satellite rainfall estimation, IAHS-AISH Publication, 359, 7-13, 2013a.

Fisher, B. L.: Climatological Validation of TRMM TMI and PR Monthly Rain Products over Oklahoma, J. Appl. Meteor., 43, 519-535, 2004.

Glabsey, C. A., Cooper, G., and McGechan, M. B.: Disaggregation of daily rainfall by conditional simulation from a point-process model, J. Hydrol., Amsterdam, 165, 1-9, 1995.

Gonçalves, L. S.: Relations intensity-duration-frequency-based satellite rainfall estimates (Relações intensidade-duraçãofrequência com base em estimativas de precipitação por satélite), Dissertação (Mestrado em Engenharia de Recursos Hídricos e Saneamento Ambiental). Universidade Federal do Rio Grande do Sul, Instituto de Pesquisas Hidráulicas. Porto Alegre, RS, 135 pp., 2001.

Hershfield, D. M. and Wilson, W. T.: Generalizing of rainfallintensity-frequency data, IUGG/IAHS publication No. 43, 499$506,1958$.

Huffman, G. J., Adler, R. F., Bolvin, D. T., and Nelkin, E. J.: The TRMM Multi-satellite Precipitation Analysis (TMPA). Chapter 1 in Satellite Rainfall Applications for Surface Hydrology, edited by: Hossain, F. and Gebremichael, M., Springer Verlag, ISBN: 978-90-481-2914-0, 3-22, 2010.

Kummerow, C., Simpson, J., Thiele, O., Barnes, W., Chang, A. T. C., Stocker, E., Adler, R. F., Hou, A., Kakar, R., Wentz, F., Ashcroft, P., Kozu, T. Hong, Y., Okamoto, K., Iguchi, T., Kuroiwa, H., Im, E., Haddad, Z., Huffman, G., Ferrier, B., Olson, W. S., Zipser, E., Smith, E. A., Wilheit, T. T., North, G. Krishnamurti, T., and Nakamura, K.: The status of the Tropical Rainfall Measuring Mission (TRMM) after two years in orbit, J. Appl. Meteorol., 39, 1965-1982, 2000.

Koutsoyiannis, D.: Statistics of extremes and estimation of extreme rainfall:1. Theoretical investigation, Hydrol. Sci. J., 49, 575-590, 2004.

Koutsoyiannis, D. and Baloutsos, G.: Analysis of a long record of annual maximum rainfall in Athens, Greece, and design rainfall inferences, Nat. Hazards, 29, 29-48, 2000.

Koutsoyiannis, D. and Xanthopoulos, T.: A dynamic model for short-scale rainfall disaggregation, Hydrol. Sci. J., Oxford, 35, 303-322, 1990.

Nicholson, S. E., Some, B., McCollum, E., Nelkin, E., Klotter, D., Berte, Y., Diallo, B. M., Gaye, I., Kpabeba, G., Ndiaye, O., Noukpozounkou, J. N., Tanu, M., Thiam, A., Toure, A. A., and Traore, A. K.: Validation of TRMM and Other Rainfall Estimates with a High-Density Gauge Dataset for West Africa, Part 
II: Validation of TRMM Rainfall Products, J. Appl. Meteor., 42, 1355-1368, 2003.

Nóbrega, R. S., Souza, E. P., and Galvíncio, J. D.: TRMM precipitation estimates analysis in a Western Amazon's sub-basin (Análise da estimativa de precipitação do TRMM em uma subbacia da Amazônia Ocidental), Rev. Geogr., 25, 6-20, 2008.
Rodriguez-Iturbe, I., Cox, D. R., and Isham, V.: A point process model for rainfall: further developments, P. Roy. Soc. London, Series A, 417, 98-238, 1987.

Rossato, M. S.: The climates of Rio Grande do Sul: variability, trends and tipology (Os climas do Rio Grande do Sul: variabilidade, tendências e tipologia), Doc., Programa de Pós-Graduação em Geografia, Universidade Federal do Rio Grande do Sul, Porto Alegre, 240 pp., 2011. 